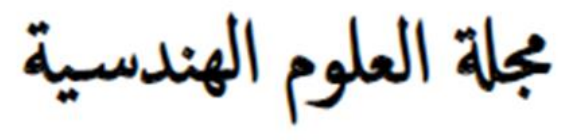

\title{
Light Live load Bridges over the River Nile in Sudan
}

\author{
Ahmed Gasim M. Hussein ${ }^{1, *}$ and Khalil Fawzi Ajabani² \\ 1 Civil Engineering Department, Omdurman Islamic University, Omdurman, Sudan \\ 2 Civil Engineering Department, National University, Khartoum, Sudan \\ * Corresponding author: Ahmed Gasim M. Hussein (e-mail: ahmedgasim@gmail.com).
}

Article history: Received 14 March 2020, Received in revised form 4 November 2020, Accepted 11 November 2020

\begin{abstract}
Bridge structures are vital for majority of Sudanese due to the fact that they live besides rivers, valleys and inside islands. Bridge construction is faced by the fact that it is extremely expensive. Cost of such structures is affected by live load which accordingly dictates the required dead Loads from both superstructure and substructure. In this analytical study a light live bridge load is derived making use of AASHTO principles. This practical live load is derived from data collected from sedan cars, bicycles, motorcycles, motorcycles rickshaws, auto rickshaws and pedestrian. The derivation yielded a design light live load composed of design lane load and design vehicle; to be applied simultaneously to this type of light bridges. The live loads are to be controlled at the bridge entrance. The derived loads are applied to different superstructures' systems, namely steel truss and composite steel plate girder. A single pier over two piles substructure system is chosen for such light loads. A case study bridge is designed over the River Nile. The results obtained showed tremendous savings in material and cost. Relative to normal highway bridges over the Nile, the steel truss bridge option reduces the cost by almost $60 \%$.
\end{abstract}

Keywords: AASHTO, Cost, Light live Loads, Steel Plate girder, Truss.

\section{INTRODUCTION}

\section{A. Overview}

Bridge structures are vital for majority of Sudanese due to the fact that they live besides the River Nile and its attributes, other rivers and water passes, valleys and inside islands. Bridge construction is faced by the fact that it is extremely expensive .Cost of such structures is affected by live load magnitude which accordingly dictates the required dead Loads from both superstructure and substructure. Normally, the optimum bridge design convention is when the ratio of cost of super structure to substructure is 1:1, i.e. $50 \%$ each [1]. By minimizing the live loads, lighter structural forms of superstructure can succeed to withstand these light live loads. The recent long bridges constructed in Sudan during the last 25 years are all highway bridges designed for standard highway live loads. Bridge live loads standards normally followed in Sudan are either.
The British Standard BS 5400 [2] or the American AASHTO specifications [3]. For such highway live loads the bridge elements are designed for extreme loaded trucks that yield voluminous elements with extreme high capacities. Such transferred high loads form superstructure; both live and dead loads; imply a voluminous substructure. The resultant design will be markedly very costly. The average cost per square meter of six recent highway bridges constructed in Sudan is $1860 \$ / \mathrm{m}^{2}$ [4]. This imply that to best estimate that superstructure cost is not less than $830 / \mathrm{m}^{2}$, although internationally the cost is much higher [5].

\section{B. Why light live load bridges?}

In a capital like Khartoum, the amount of sedan cars and other light means of transport constitute more than $80 \%$ of the traffic volume. Theses light live load vehicles includes; in addition to sedan cars; bicycles, motorcycles, motorcycles 
rickshaws, auto rickshaws and pedestrian. The magnitude of live loads for such transport means is far low than standard highway loads. This large amount of share in traffic volume now uses the available highway bridges. With the increasing demand for bridge structures in Khartoum; as explained in its mobility master plan [6]; it is logical to design some bridges for such light live loads. This analytical study will show how such light live load will be derived, and how it will save a lot of the cost.

\section{Objective:}

The objective of this study is to derive a suitable bridge live load to represent the light traffic crossing bridges over The River Nile in Sudan, and to use such live loads for cost effective bridge designs.

\section{STANDARD HIGHWAY LIVE LOADS}

A. The commonly used highway live loads in Sudan are the British Standard BS 5400 [2] and the American AASHTO LRFD specification for design of Highway Bridges [3].Figures 1 and 2 show the magnitudes of such live loads. Clearly their values are far much greater than the majority of cars and other means using national bridges.

\section{B. Bridge Live Loads to BS5400[2]}

An HA loading with or without HB loading is applied to the bridge loaded span. HA Loading is composed of a Knife Edge Load (KEL) of magnitude $120 \mathrm{kN} / \mathrm{m}$ of lane together with Uniform Distributed Load (UDL) as shown in Fig.(1). The width of the design lane ; known as notional lane; is $3000 \mathrm{~mm}$. HB loading is shown in Fig.(2). Alternatively, a single wheel load of $100 \mathrm{kN}$ can be applied to generate pressure of 1.1 $\mathrm{N} / \mathrm{mm}^{2}$.

\section{American AASHTO-LRFD Highway Live Loads [3]}

This load is composed of a Design Truck (Fig. 3), or Design Tandem (Fig. 4), in addition to Design Lane Which is $9.3 \mathrm{kN} / \mathrm{m}$ of lane

The design tandem is a pair of two concentrated loads $110 \mathrm{kN}$ each, spaced $1200 \mathrm{~mm}$ apart. Width of the design lane load is $3000 \mathrm{~mm}$.

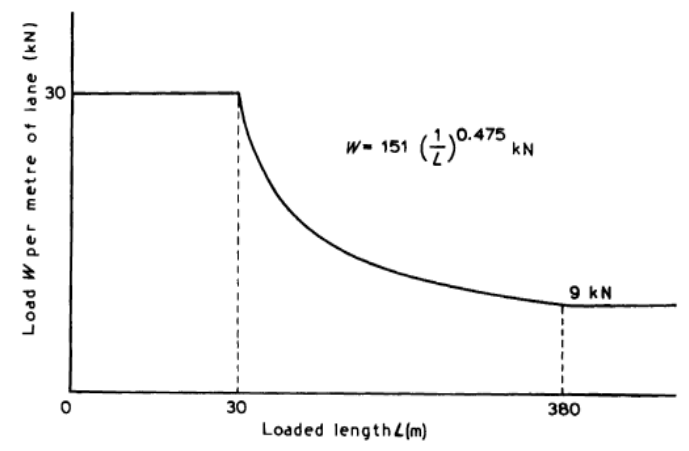

Fig.1. HA -UDL British Live Load.

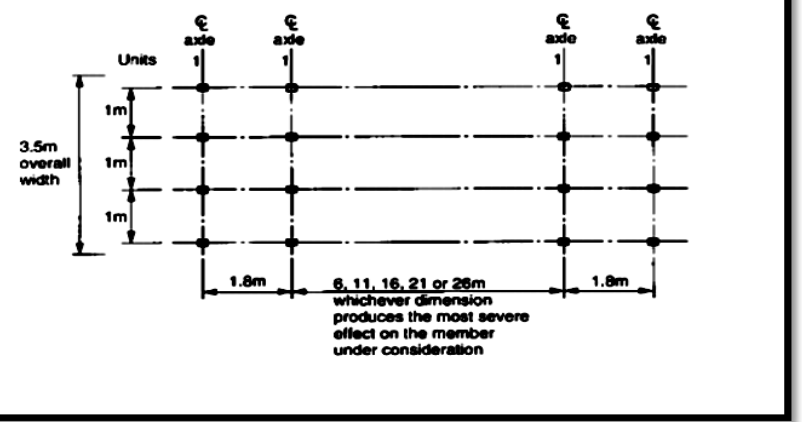

Fig. 2. HB British loads.

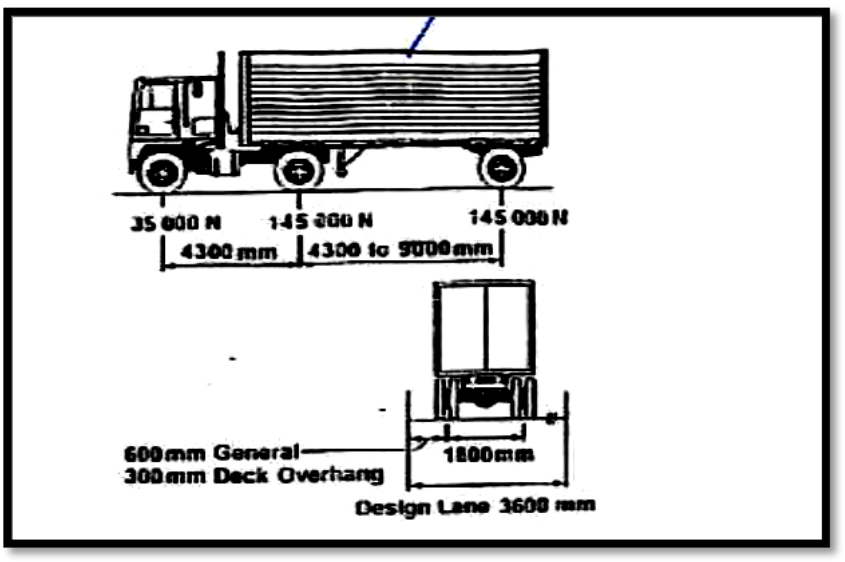

Fig. 3: AASHTO Design Truck.

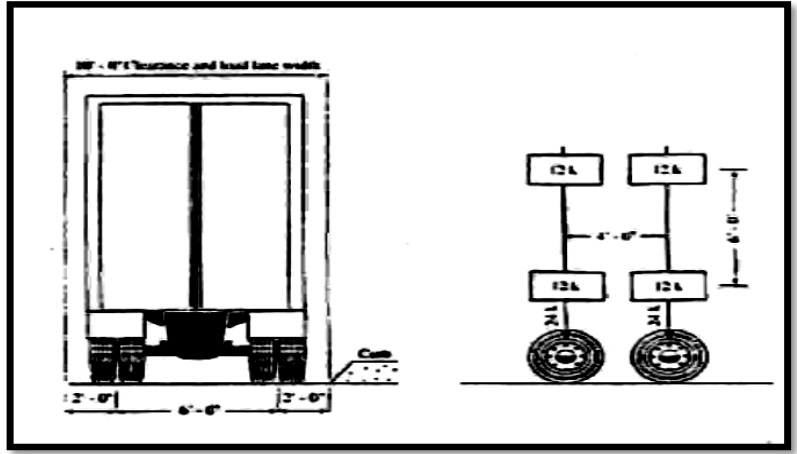

Fig. 4: AASHTO Design Tandem.

\section{RESEARCH METHODOLOGY}

A. Loads data of targeted light vehicles types are collected. This include sedan (saloon) cars, three-wheeled motorcycles, motorcycle rickshaws and pedestrians. Data collected are from the manufacturer's websites, showing relevant 
technical specifications of loads and dimensions.

B. From load data, and following the trend of AASHTO standard Specifications of Highway Bridges [3]; [7], a design load combination is derived to represent light live loads. This design load is composed of a uniformly distributed live load per linear meter of design lane (UDL/m of lane), together with a design vehicle. Both loads are to be applied to the bridge concurrently as they will be shown.

C. As the bridge is a light bridge, the width of the bridge will be just to be enough for the targeted vehicles. Accordingly the width of the design lane loaded by the design UDL is taken as

$2000 \mathrm{~mm}$.

$D$. Two bridges' superstructures types are considered. First is a composite steel plate girder bridge; second is a steel truss bridge. For the two alternatives a single concrete pier on a two pile system is chosen for substructure. Each bridge span of $30 \mathrm{~m}$ is assumed to be simply supported over the piers.

E. Bridge analysis is made for the two alternatives. Simplified and Finite element analysis software is used. Design is made considering AASHTO LRFD principles.

Analysis and design results are presented and compared. The optimum design is selected and then compared material and pricewise with normal highway bridges constructed in Sudan during the last 20 years. Conclusions then are given.

\section{GENERATION OF BRIDGE LIGHT LIVE LOADS}

\section{A. Sedan Cars Loads}

The major type of vehicles using bridges in the capital Khartoum is the sedan cars. Table I below shows load data and dimensions of some of these cars extensively used as means of transport. Also the equivalent distributed load $/ \mathrm{m}^{2}$ for each car is given, assuming the car total load is distributed over an area of:

Area $=$ car length $\mathrm{x}$ width of design lane or:

$$
\text { Area }=\text { Lcar } \times 2.0 \mathrm{~m}^{2}
$$

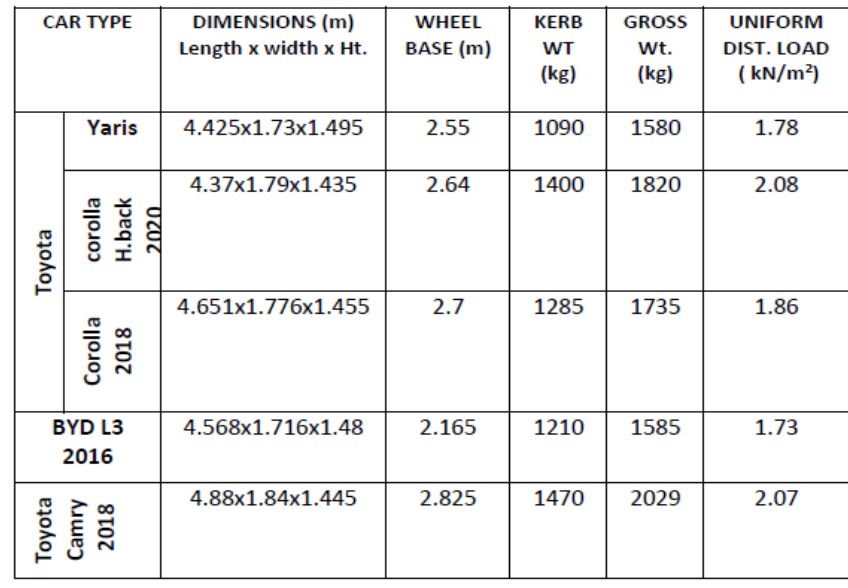

\section{B. Three Wheeled Motorcycles and Motorcycle Rickshaws Loads}

During the last 25 years, the numbers of three wheeled motorcycles and motorcycle rickshaws, used as means of transport in the capital Khartoum, are rapidly increasing year by year. The registered number at 2014 reached over 90000 ones [8]. Load and dimension data of such vehicles are collected from their manufacturers and summarized in Table II below. Also equivalent distributed load $/ \mathrm{m}^{2}$ are calculated over a design lane width of $2.0 \mathrm{~m}$ and area of:

Area $=$ Lrickshaw $\mathrm{X} 2.0 \mathrm{~m}^{2}$

TABLE II: THREE WHEELED MOtORCYCLeS AND MOTORCYCle RICKSHAWS LOADS DATA

\begin{tabular}{|c|c|c|c|c|c|}
\hline $\begin{array}{l}\text { Vehicle } \\
\text { TYPE }\end{array}$ & $\begin{array}{c}\text { DIMENSIONS } \\
(\mathrm{m}) \\
\text { Length } \mathrm{x} \text { width } \mathrm{x} \\
\mathrm{ht}\end{array}$ & $\begin{array}{l}\text { WHEEL } \\
\text { BASE }(\mathrm{m})\end{array}$ & $\begin{array}{l}\text { KERB } \\
\text { WT } \\
(\mathrm{kg})\end{array}$ & $\begin{array}{l}\text { GROSS Wt. } \\
\text { (kg) }\end{array}$ & $\begin{array}{r}\text { UNIFORM } \\
\text { DIST. LOAD } \\
\left(\mathrm{kN} / \mathrm{m}^{2}\right)\end{array}$ \\
\hline $\begin{array}{l}\text { Rickshaw } \\
\text { Lovson }\end{array}$ & 2.x1.3x1.074 & - & 290 & 540 & 1.35 \\
\hline $\begin{array}{l}\text { Rickshaw } \\
\text { Biagio }\end{array}$ & $2.7 \times 1.37 \times 1.72$ & 1.92 & 365 & 765 & 1.41 \\
\hline $\begin{array}{c}\text { Rickshaw } \\
\text { Lovson LL2 }\end{array}$ & $\begin{array}{c}2.665 \times 1.345 \times 1 . \\
73\end{array}$ & 2020 & 290 & 650 & 1.21 \\
\hline $\begin{array}{l}\text { Wanhu } \\
\text { Rickshaw }\end{array}$ & $\begin{array}{c}2.65 \times 1.295 \times 1.6 \\
95\end{array}$ & _ & 345 & 540 & 1.02 \\
\hline $\begin{array}{c}\text { Wanhu } \\
\text { passenger } \\
\text { Tricycle }\end{array}$ & $2,64 \times 1.36 \times 1.72$ & 2000 & 450 & 645 & 1.22 \\
\hline $\begin{array}{c}\text { Humsafar } \\
\text { Cargo } \\
\text { Rickshaw }\end{array}$ & $3.05 \times 1.505 \times 1.7$ & 1945 & 440 & 950 & 1.55 \\
\hline $\begin{array}{c}\text { Giad Heavy } \\
\text { Loading } \\
\text { Tricycle }\end{array}$ & $3.5 \times 1.3$ & 2.3 & 460 & 2000 & 2.85 \\
\hline
\end{tabular}

\section{Derivation of Design light Live Load}

Considering the load data from the above 
tables, we proceed to derive an equivalent design live load. Following the same pattern used to derive AASHTO ( HL- 44 )live loads of the Standard Specifications for Highway Bridges[7], and ( HL-93) live loads of AASHTO- LRFD Design Specifications of Highway Bridges [3 ], the suggested design light live load will be composed of two parts:

(a) Uniformly Distributed Lane Load.

(b) Design Vehicle.

The total design light live load will be the effect of both loads to give critical force effects.

\section{Design Lane Load}

It is the value of intensity of live load equivalent to the load applied to the bridge by a train of vehicles, nose to nose in our case, covering a selected width of $2.0 \mathrm{~m}$. From above tables the safe UDL $/ \mathrm{m}^{2}$ is approximated to $3.0 \mathrm{kN} / \mathrm{m}^{2}$ implying a design Lane Load of $6.0 \mathrm{kN} / \mathrm{m}$ of lane. The design lane load is not liable to dynamic load allowance.

\section{E. Design Vehicle}

The design vehicle is a hypothetical one that represents the severe force effects on the loaded span as the effect of concentrated loads from vehicle axles. The derivation of the design vehicle is based on the same procedure followed in deriving AASHTO (HL-44) and (HL-93) Standard Trucks [3], [7]. The derived design truck is a two axle vehicle of total load of $60 \mathrm{kN}$ shared between the axles in the ratio of 1:2 between front and rear axle; i.e. $20 \mathrm{kN}$ and $40 \mathrm{kN}$ respectively. Axles are $2.3 \mathrm{~m}$ apart. Fig. 5 shows the configuration of the selected design vehicle. Design vehicle load effects are liable to dynamic load allowance as per AASHTO-LRFD Design Specifications [3]. Design vehicle is applied in one location on the loaded span together with the design lane load.

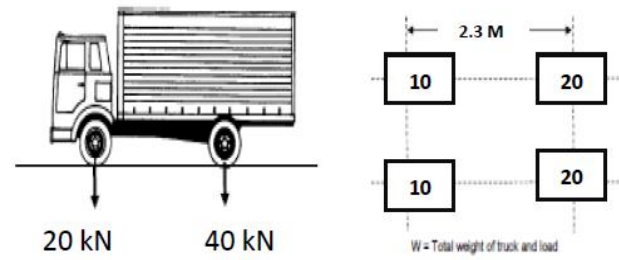

Fig. 5 LLLB Design Vehicle.

\section{F. Pedestrian Loads}

Pedestrian load is taken as in AASHTO-LRFD
Bridge Design Specifications.

\section{CASE STUdY: LigHt LiVE LOAD BRIDGE OVER THE RIVER NILE IN KHARTOUM}

\section{A. Location}

Several locations can be selected. For this case study a bridge linking Omdurman to Khartoum North - south of Halfaya Bridge - beside the transmission towers line is suggested. The total span is $660 \mathrm{~m}$, divided into 22 spans. Each span is $30 \mathrm{~m}$, simply supported over the piers.

B. Substructure

Each pier is a concrete, single solid wall hammered type. Two concrete piles with elevated pile cap support the pier shank.

\section{Superstructures}

Two alternatives are considered for the superstructure; composite plate girder or truss steel bridges. The following sections tackle analysis and design of the two options.

\section{STEEl Composite Plate GIRDER BRIDGE}

\section{A. Layout and design Criteria}

The Bridge is a 2-lane bridge; with 2 side footpaths as the x-section shown in Fig. 6 .Total width is $8.4 \mathrm{~m}$. A $20 \mathrm{~cm}$ concrete deck is compositely carried over steel plate girders $1.2 \mathrm{~m}$ apart.

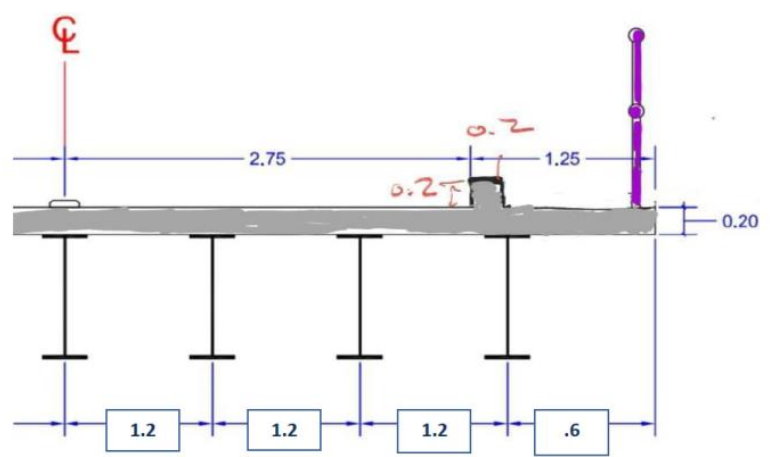

Fig. 6. Composite Plate Girder Bridge X-section.

Other design criteria are as follows:

Span

$: 30 \mathrm{~m}$

Structural Steel Grade $\quad$ : A-50

Structural steel yield strength $\quad: 345 \mathrm{~N} / \mathrm{mm}^{2}$

Reinforcing steel yield strength $\mathrm{F}_{\mathrm{y}}: 420 \mathrm{~N} / \mathrm{mm}^{2}$

Concrete compressive strength $\mathrm{f}_{\mathrm{c}}{ }^{\prime}: 30 \mathrm{~N} / \mathrm{mm}^{2}$

Asphalt wearing surface $\quad: 25 \mathrm{~mm}$

Live Loads: suggested BLLL (bridge light live 
Load) + ASHTO-LRFD Pedestrian Load

\section{B. Analysis}

Analysis were performed using simplified analysis or Autodesk Robot Structural Analysis Professional software. Results obtained for interior girder for maximum force effects along the girder length are shown in the following Table.

Table III: Max. Force Effects along Interior Plate Girder.

\begin{tabular}{|c|c|c|}
\hline \multirow{4}{*}{ 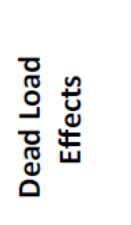 } & $M_{D C}$ & 788 kN.m \\
\hline & $V_{D C}$ & $105 \quad \mathrm{kN}$ \\
\hline & $M_{D W}$ & 112.5 kN.m \\
\hline & $V_{D W}$ & $15 \mathrm{kN}$ \\
\hline \multirow{4}{*}{ 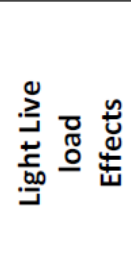 } & Lane Load Moment $\mathrm{M}_{\mathrm{L}}$ & 405 kN.m \\
\hline & Lane Load Shear $V_{L}$ & $54 \mathrm{kN}$ \\
\hline & Vehicle Moment $M_{v}$ & $450 \mathrm{kN} . \mathrm{m}$ \\
\hline & Vehicle Shear $V_{V}$ & 58.5 \\
\hline
\end{tabular}

\section{Design}

Design is performed according to AASHTO-LRFD design method for composite plate girder bridges. The design procedure yielded the design selections shown in the Fig. 7.

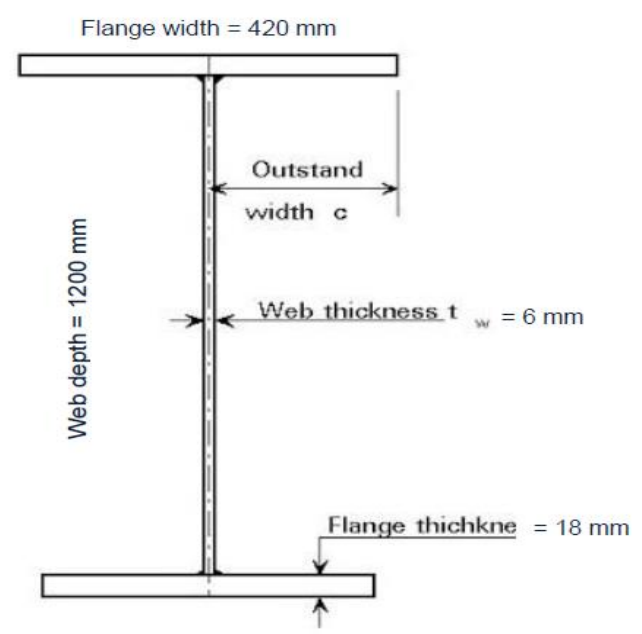

Fig. 7 . Designed X-section of Interior Plate Girder.

\section{STEEL TRUSS BRIDGE}

\section{A. Layout and design Criteria}

A steel truss bridge $30 \mathrm{~m}$ length and $8.4 \mathrm{~m}$ width is considered in this option.

The bridge superstructure is composed of the following:

(a) Deck: a $20 \mathrm{~cm}$ concrete deck is supported by
Series of longitudinal steel stringers spaced $1.2 \mathrm{~m}$ apart. The stringers are supported on transverse steel floor beams spaced every $3 \mathrm{~m}$. Floor beams, $8.4 \mathrm{~m}$ length are fixed at their ends to two end main trusses.

(b) Two Main Trusses: at the sides of the bridge deck. Each truss is of $30 \mathrm{~m}$ length and $3.0 \mathrm{~m}$ high; composed of 10 fields each is $3.0 \mathrm{~m}$, as shown in Fig. 8. The floor beams are connected at nodes 1-11 at the bottom chords.

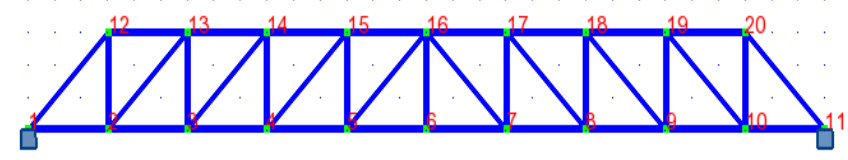

Fig.8: Truss Bridge Elevation.

The other design criteria for structural steel, reinforcing steel and concrete strength are the same as for the plate girder option.

B. Analysis and Design

(a) The following assumptions are made:

1. Concrete deck is composite with the Stringers

2. Stringers are continuous over the floor beams, and the floor beams are fixed at the trusses.

3. Own weights for stringers and floor beams are increased by $20 \%$ for their connections; whereas for trusses increased by $30 \%$.

Bracing loads are considered.

4. Bolted pinned trusses are chosen, for ease of analysis and erection.

(b) Analysis and design are made for the deck's steel stringers and floor beams; for both dead and light live effects as per Strength I limit state of AASHTO-LRFD specifications. Output of the results are shown in Table IV.

(c) Analysis and design are made for the truss elements; for both dead and light live effects as per Strength I limit state of AASHTO-LRFD specifications. The elements are grouped as tension members, compression members, hangers and diagonals. Output of the results are shown in Table V. Clearly these elements represents half the truss due to symmetry.

Table IV: Analysis and design summary for Stringers and floor beams-Truss option. 


\begin{tabular}{|c|c|c|}
\hline Load Effects & Stringer & Floor Beam \\
\hline $\begin{array}{l}\text { Dead Load } \\
\text { Moments } \\
\text { DLM }\end{array}$ & $\begin{array}{l}\mathrm{MDC}=5.6 \mathrm{kN} \cdot \mathrm{m} \\
\mathrm{MDW}=0.6 \mathrm{kN} \cdot \mathrm{m}\end{array}$ & $\begin{array}{l}\mathrm{MDC}=120 \mathrm{kN} \cdot \mathrm{m} \\
\mathrm{MDW}=13 \mathrm{kN} \cdot \mathrm{m}\end{array}$ \\
\hline $\begin{array}{l}\text { Live load } \\
\text { Moment }\end{array}$ & $\begin{array}{l}\mathrm{ML}=3.24 \mathrm{kN} \cdot \mathrm{m} \\
\mathrm{MV}=16.42 \mathrm{kN} \cdot \mathrm{m}\end{array}$ & $\begin{array}{c}\mathrm{ML}=71 \mathrm{kN} \cdot \mathrm{m} \\
\mathrm{MV}=168 \mathrm{kN} \cdot \mathrm{m}\end{array}$ \\
\hline $\begin{array}{c}\text { Dead load Shear } \\
\text { kN }\end{array}$ & $\begin{array}{l}\mathrm{VDC}=9.24 \mathrm{kN} \\
\mathrm{VDW}=1.0 \mathrm{kN}\end{array}$ & $\begin{array}{l}V D C=65 \mathrm{kN} \\
V D W=7 \mathrm{kN}\end{array}$ \\
\hline $\begin{array}{l}\text { Live load Shear } \\
\text { kN }\end{array}$ & $\begin{array}{c}V L=5.4 \mathrm{kN} \\
V V=16.42 \mathrm{kN}\end{array}$ & $\begin{array}{l}\mathrm{VL}=37.8 \mathrm{kN} \\
\mathrm{VV}=40 \mathrm{kN}\end{array}$ \\
\hline Selected Section & $\begin{array}{c}\text { UB 203x133x25 } \\
\mathrm{kg} / \mathrm{m}\end{array}$ & UB 610x178x82 \\
\hline
\end{tabular}

\section{DISCUSSION OF RESULTS}

\section{A. Comparison of steel weights of both}

\section{Options:}

From the above results the amount of steel used for both options can be calculated as:

(a) For plate girder bridge option:

$\mathrm{Wt}=(\mathrm{Own} w \mathrm{wt} / \mathrm{m}+$ connection $) \times 30 \mathrm{~m} \times 8$ girders $\mathrm{Wt}=520 \mathrm{kN}$

(b) For Truss bridge option:

$\mathrm{Wt} .=$ Stringers $+\mathrm{X}$. Beams + Trusses + Bracing $\mathrm{Wt} .=320 \mathrm{kN}$

Clearly the truss option is lower cost material-wise.

Table V: Design Summary-Truss elements.

\begin{tabular}{|c|c|c|c|c|c|c|}
\hline $\begin{array}{c}\text { Member } \\
\text { Type }\end{array}$ & Member & $\begin{array}{l}\text { Length } \\
\text { (m) }\end{array}$ & $\begin{array}{l}\text { Design } \\
\text { force } \\
(\mathrm{kN})\end{array}$ & $\begin{array}{l}\text { Selected } \\
\text { Section }\end{array}$ & $\begin{array}{c}\text { Mass/m } \\
(\mathrm{kg})\end{array}$ & $\begin{array}{c}\text { Total } \\
\text { Mass } \\
\text { (kg) }\end{array}$ \\
\hline \multirow{3}{*}{ 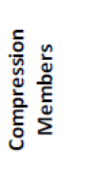 } & End Post & 4.24 & 764 & UB $457 \times 152 \times 52$ & 52 & 220 \\
\hline & $\begin{array}{c}2^{\text {nd }} \& 3^{\text {rd }} \\
\text { upper }\end{array}$ & 6.0 & 960 & UB $457 \times 152 \times 52$ & 52 & 312 \\
\hline & $\begin{array}{l}4^{\text {th }} \& 5^{\text {th }} \\
\text { upper }\end{array}$ & 6.0 & 1440 & UB 457x191x98 & 98 & 588 \\
\hline \multirow{3}{*}{ 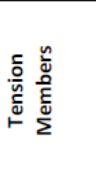 } & $\begin{array}{l}1^{\text {st }} \text { Left } \\
\text { Lower }\end{array}$ & 3.0 & 540 & UB $406 \times 140 \times 39$ & 39 & 117 \\
\hline & $\begin{array}{l}2^{\text {nd }} \& 3^{\text {rd }} \\
\text { Lower }\end{array}$ & 6.0 & 1260 & UB $406 \times 140 \times 46$ & 46 & 276 \\
\hline & $\begin{array}{l}4^{\text {th }} \& 5^{\text {th }} \\
\text { lower }\end{array}$ & 6.0 & 1500 & UB $610 \times 178 \times 82$ & 82 & 492 \\
\hline \multirow{2}{*}{ 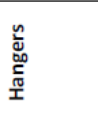 } & $1^{\text {st }}$ Left & 3.0 & 420 & 2L 76x76X9.4 & 10.57 & 64 \\
\hline & $\begin{array}{l}2^{\text {nd }}, 3^{\text {rd }}, 4^{t} \\
\text { n } \& 5^{\text {th }}\end{array}$ & 12.0 & 300 & $2 \mathrm{~L} 64 \times 64 \times 7.9$ & 7.45 & 179 \\
\hline Diagonals & All & 16.96 & 594 & 2L 89x89x15.8 & 20.1 & 682 \\
\hline Total & & & & & & 2930 \\
\hline
\end{tabular}

B. Total cost of superstructure under light live loads The total cost of the superstructure $/ \mathrm{m}^{2}$ is the sum of cost of concrete deck and steel including erection. To our best estimate and according to current prices for similar projects this can calculated as:

(a) Cost of steel component (truss option):
(32 tons $\left./ 30 \times 8.4 \mathrm{~m}^{2}\right) \times \$ 2000=\$ 254 / \mathrm{m}^{2}$

(b) Cost of reinforced concrete deck:

$0.2 \mathrm{~m}^{3} \times \$ 300 / \mathrm{m}^{3}=\$ 60$

Total cost $/ \mathrm{m}^{2}$ of superstructure $=\$ 314 / \mathrm{m}^{2}$

Now, it is clearly that this value represents: $(\$ 314 / \$ 830)=38 \%$ of current superstructures When designed under normal standard highway loads.

\section{Ease of Erection}

The heaviest element in our options is the truss of total gross weight less than 7 tons. Any erection procedure can suit such light structural elements.

D. International trend to revise live loads:

All standard highway live loads are old enough to be revised. The recent one is the AASHTO HL-93 live loads; 27years old. Actually, recent research asked for such updating [9].

\section{E. Analysis results:}

Clearly the magnitudes of LLL is much less than those of standard highway loads. Design light lane load is only $(6 \mathrm{kN} / 9.3 \mathrm{kN}) / \mathrm{m}$ of lane compared to HL-93. And light design truck is only (60kN/225kN) compared to HL-93 Truck. Results obtained is reasonable considering these facts.

\section{CONCLUSIONS AND RECOMMENDATIONS}

A. The following conclusions can be derived from this study

(a) Bridge Light live loads have been derived to represent major share of traffic volume crossing bridges in Khartoum, capital of Sudan and other Sudanese similar cities.

(b) Derived bridge light live loads are applied to options of steel superstructures. The design yielded bridges that save $60 \%$ compared to normal highway bridges.

(c) The steel truss bridge option is the most economical option.

\section{B. It can be recommended that}

(a) For bridges carrying light live load, as in large cities like Khartoum, it is recommended to consider such derived light live loads, and to design special bridges for such loads. This will yield considerable cost savings.

(b) Research is to be extended to study other limit states and other steel superstructures types 
(box girders, orthotropic decks etc.)

\section{REFERENCES}

[1] Collin O'Connor, Design of Bridge Superstructures, 1st ed., Wiley-Interscience, 1971.

[2] AASHTO Executive Office, AASHTO LRFD Bridge Design Specifications, 5th edition, 2007.

[3] British Standards Institution," BS 5400,

Steel, Concrete and Composite Bridges, Part II ", BSI, 1978.

[4] Hashim M. Ahmed Elbashir," Selection of Appropriate Construction Methods for Bridges", M.Sc. Thesis, Karary University,Sudan,2011, Table (4.6), pp 101.

[5] Florida Department of Transportation, Structures Design guidelines, FDOT Structures Manual, Vol. 1, January 2014.

[6] Khartoum State and MEFIT Ltd. ,"Khartoum Transport and Mobility Master plan; 2010-2035; Executive Summary", Khartoum ,2013.

[7] AASHTO Executive Office, "AASHTO Standard Specifications of Highway Bridges", 14th edition, 1989.

[8] Khartoum State, Cabinet Council,' Committee Report of Rickshaws and 3-Wheeled motorcycles ', Khartoum, Sudan, 2015.

[9] Linda Kaplan," AASHTO Vehicle Live Loading", Structure magazine, April 2020; www.strucuremag.org/?p=15753. 